\title{
Discussion on the Future Development Trend of Domestic Art Design Education and the Comparison with Italy Design Education
}

\author{
Li Zhu', a, Li Wei ${ }^{2}$ \\ ${ }^{1}$ Shanghai Art \& Design Academy, Shanghai 201808, China \\ ${ }^{2}$ School of Art, Nanjing University of Aeronautics and Astronautics, Nanjing 211106, China \\ alz163yx@163.com
}

Keywords: Art and design education in Italy; domestic art design; development trend.

\begin{abstract}
From archaeological point of view, there are human beings, art and art design. Art and design throughout the course of human development, but also to the quality of human life has been improved. Art is a unique way of expressing inner thoughts and feelings in the process of human development. Artistic design has improved the quality of human life and optimized productivity. People in different regions have the same and different artistic understanding and design practice, and their works have similarities and differences. Mainly affected by geographical characteristics, humanistic thinking, lifestyle and other factors. There are some differences in the education of art design because of the different regions, which is closely related to the evolution of the types and forms of the works created by different regional cultural soil. Nowadays, the difference of art and Design Education between China and the West has been paid more and more attention. Through the study of the differences between Chinese and Western art design and education, we can examine the art and design education in China from an international perspective, and promote the perfection and development of art and design education in china. For a country, the excellent degree of art design education not only represents the civilization degree of this country and nation, but also influences the future development of this country to a certain extent.
\end{abstract}

\section{Introduction}

Art design originates from art, and is an integral part of art. It also has a long history with art. China's art design education originated from the beginning of the last century, promulgated the "charter school will be played", from that moment, the art design education in China before the official track, are traditional artists between heart legend. The formal establishment of art education is of great significance to the education of art and design in china. The origin of Western art design education earlier, there have been nearly five hundred years of history, Italy is also the western art and design on behalf of the state, so the emergence and development of art design education in China is influenced by Western art design education development concept and design method of large. Until now, influenced by the background of regional culture and social development, there are still many differences between Chinese and Western art and design education in many ways. The pursuit of Western art and design education is the freedom of creation and art, the actual creative skills secondly, the requirement is to close to nature, close to society. The art design education in China focuses on the pursuit of details, and the way of education is exquisite and exquisite. Evaluation of students' theoretical knowledge and skills with the result of examination. Through the above, it can be seen that China and the West have particular emphasis on art and design education. Knowing its advantages and avoiding its disadvantages are of practical significance to the education of art and design in China. Therefore, for Italy, we focus on analyzing its advantages so as to draw lessons from it, and its insufficiency is not the content of this article.

\section{The analysis of art and design education in Italy}

Italy has an irreplaceable position in the history of art, and is regarded as one of the important 
models of art and design education in Europe and Western countries. Italy as the Second World War belligerent, has been vigorously support the US led NATO countries in World War II after the failure, put forward strategy design and in twentieth Century 50s and 60s, the rapid development of economy, in the process of economic development in Italy in the arts and culture, hope to get rid of the bondage of American culture. The art design in the context of the national documents, in the process of experiencing the Bauhaus Art design concept and seeking innovation breakthrough, Italy art and design education has experienced many large-scale reform and innovation, and gradually formed its own characteristics. It is the core goal of Italy art education to make everyone in the country accomplish self-development and realize self value. The government attaches great importance to the development of the people themselves and provides opportunities for education to everyone who is willing to receive art education, including those who are physically and mentally deficient. At present, China also pays more and more attention to the art popularization education of the people, but whether it is from the government support or people's cognitive understanding, there is still a big gap between Italy and other western developed countries.

\subsection{The cultivation of creative ability is the key to the education of art and design in Italy}

Art design teaching in Italy is a two-way teaching model to produce a works of art and design is between the teachers and students together to complete the art design results do not require how mature and great, can achieve good results, but pay attention to the process of the participation of teachers and students, let the students to be able to use your hands to finish it works of art, and in the process of creation feeling of art design philosophy, the teaching achievement is created by teachers and students. This kind of teaching concept and mode of "innovation" makes students get all-round training in the process of art design learning, and this process also enlightens students' innovative consciousness and ability.

Encourage innovation can be said to be the key to Italy art design education, because art development cannot do without innovation, in the process of innovation for the personality of students to give full play to the space, in the process of students' innovation in the creative might have excellent works, and students are likely to become the next Sottas (Ettore Sottsass). The innovation of art design education is rooted in the traditional art foundation in Italy, the only way to the progress of society, the perfect combination of tradition and innovation in education and play the role of educating people, art design education with its subtle qualities in education plays an irreplaceable role.

\subsection{Pay attention to the creation of artistic design environment atmosphere and the construction of facilities}

In the art schools in Italy, great attention has been paid to the creation of campus art environment atmosphere, and the display of various art works can be seen everywhere in most campuses. The interior design of the design institute is full of design, and provides a large number of public space for students to learn, exchange and design. Campus outdoor space also provides students with a lot of space to learn and communicate. Various artistic activities are frequently held outside the campus, society often carry out various levels of exhibition, World Expo, Milan Home Furnishing international exhibition, fashion week, men's week, three design exhibition, Art Biennale, Venice Biennale International Exhibition of everything. This after another rendering a thick atmosphere of art design.

School of education facilities construction also attaches great importance to international exchange center, laboratories, libraries, museums, especially in the Goods are available in all varieties., University Museum has a collection of a certain number of collections, which are influential in the history of design master works.

\subsection{The art basic education has laid a solid foundation for art design education}

Italy attaches great importance to the basic and universality of art education, and comprehensively popularized art education in primary school and junior high school, focusing on the cultivation of children's artistic creativity and basic aesthetic ability. After entering the middle 
school, students can choose their own artistic development direction according to their own personality characteristics and hobbies. Italy has eight years of compulsory education, art courses throughout the primary school stage, there is no hard and fast indicators of art courses, an average of two hours a week to open junior high school art course, also set up a theory of art curriculum, so that every student can not only meet the demand for the Arts, but also to give students more choice the right to cultivate the art in thick foundation for the art design education in the selection and training of personnel selection and lay a solid foundation.

\subsection{The relaxed teaching atmosphere is conducive to the cultivation of students' creative thinking}

Italy ancient Rome to the Renaissance to contemporary art and design, the blood is filled with art gene, this gene is in the art design education also reflects certain art, its teaching have great autonomy, every school has its own characteristics, each professor can also have their own set of standards. There is no fixed classroom model in classroom teaching, there is great freedom for students to play space, design topics and design direction can be chosen independently, the focus of art design education is to cultivate students' creative thinking and artistic creation ability. Mainly reflected in two aspects: first, the expansion and promotion of theoretical knowledge; two is the specific design process of teaching guidance in the course of the teacher. Therefore, the design of professional courses, design theory courses in Italy art and Design Institute status is equally important.

\section{Analysis of art and design education in China}

\subsection{The long history and the slow development of Art Design Education}

China has a long history, ancestors left a lot of art treasures, is still admired by later generations. Although the origin of art in China was early, the education started late. Confucius said: "not, then good old." Before China's modern art education is to follow this old saying. Based on the teaching requirements under the teaching mode, containing the ancestor worship and inheritance, in the process of passing and no clear combination of courses and teaching syllabus, the emphasis is the inheritance, imitation, inheritance, so the art education is narrow, can not be effectively extended to everyone, not to meet the people's demand for art design.

With the continuous culture of modern western art, Chinese art design education concept began to appear some changes, in this period, the late Qing Dynasty, the education system of our country is mainly rely on the introduction of Western art and Japanese art education, public teaching mode is modeled on the western teaching system, and the first college of design teachers are returnees scholars, this paper attempts to design the combination of Chinese and Western culture in the field of architecture design, but because of the war and social unrest until after the establishment of the new Chinese 50s didn't start again and slow development.

\subsection{The urgent need to strengthen the cultivation of innovation ability}

Art design teaching content, form and concept of colleges and universities in China are relatively similar, pay attention to training the students' skill training, pay little attention to their innovation and creativity, design students to imitate the phenomenon of common art students due to weak foundation of creative thinking teaching mode tends to be difficult to open examination. In view of the teaching of art design in Italy University, the skill training of painting has been taken as a solution to the problem before school, and the University focuses on thinking training. Works without innovation will only become superficial. The teaching mode of our country is very different from the Western emphasis on the cultivation of students' creative ability, so to some extent, it affects the overall quality and level of art and design in china.

\subsection{The weak foundation of art education directly affects the art design education}

The basic art education in China is very weak. Under the background of examination oriented education, the basic art education has become an interdisciplinary subject. As far as the only content 
of art basic education curriculum is concerned, it is very simple compared with the painting, sculpture, design and art history of primary and secondary schools in Italy. As far as the teaching model is concerned, it is more monotonous than the colorful room sketching and Museum scene teaching in Italy. This kind of art education basis has seriously lowered the bottom line of art and design education in china.

\section{The future development trend of Art Design Education}

\subsection{Art and design education should take into account both the progress of science and technology and the development of human spiritual needs}

With the continuous development of information society, the future development of art and design education must adapt to the change of science and technology, but the simple science and technology can not meet people's pursuit of spiritual culture. The interdisciplinary nature of art and design determines that he must take into account both technology and culture. Under the background of the continuous development of science and technology in the new century, the concept of art design has changed from tangible to intangible; from material design to non-material design; from physical design to virtual physical change. The material and spiritual needs of the people have expanded from the former material carrier to the virtual carrier. Therefore, the art design education should pay attention to the transformation of this demand, gradually change the traditional narrow teaching mode and concept, to adapt to the new era of new teaching mode and teaching philosophy change.

\subsection{Art design education should be integrated into the knowledge economy concept}

People in today's society has entered the era of knowledge economy, interactive art design and the economic and social development has been a big trend of art design, in this trend under the requirements of any design thinking of the immutable and frozen and the corresponding measure is meaningless. Therefore, in the teaching process of today's art and design education, we should integrate the concept of knowledge economy, create a more reasonable space for human development.

\subsection{The development of art and design education must conform to the social and cultural background}

Art originates from life, and life is influenced by social and cultural background, so it can be said that social culture is the soil that breeds art. The traditional art design culture contains rich aesthetic and philosophical views. Traditional culture can be said to be the spiritual wealth of the whole human being. Therefore, the design idea derived from the traditional design culture is eternal vitality. In the contemporary social development background, art design thought should be based on the traditional aesthetic culture blood relationship, development of art design education should be based on the traditional idea of localization, in the process of designing the essence of Yang traditional culture into modern thoughts, and then make the art design enrich our daily life. In the course of development of design education in the future, the Confucian culture based China traditional ideas and values with the help of modern thought and technology will re radiate new vitality to the development, so we should seize this historic opportunity, standing at a new height to examine traditional thought China, art design let from Chinese traditional thought to the world.

\section{Conclusion}

In a word, in the process of art design education, to fully mobilize the students' creative thinking, from teaching philosophy, teaching mode and other aspects, to create a three-dimensional construction of students innovative teaching conditions of multi angle, so that students can play the autonomy in classroom teaching. Schools and society should also pay attention to the creation of innovative art atmosphere, so that students in a creative atmosphere in the art of learning, to improve the design ability of students has a great help. In teaching, we should recognize the 
teaching gap between Italy and other western countries, take its director, enhance our director and integrate into the forefront of science and technology, so as to better develop China's art and design education. Today, China is constantly rising, Oriental culture is also gradually affecting the world, in the art and design education should pay attention to the infiltration of traditional Chinese culture, make art design education more in line with China's national conditions, and thus improve the level of art and design education.

\section{References}

[1] Wang Shouzhi. The world of modern design history [M]. China Youth Press, 2002.

[2] Ma Chundong. Industrial design should establish a complete education system [J]. Decoration, 2005.

[3] [U.S.]Arthur D.Efland. Xing Li, Chang Ningsheng translation. A history of Western Art Education [M] Sichuan people's publishing house, 2001.

[4] [Korea] Kim Ho. Twenty-first Century design education outlook [J]. Decoration 2000.

\section{Introduction:}

Li Zhu: (1965.2 -) female, Han, Professor, Baccalaureate, Research direction: Art Design Education and practice.

Li Wei, (1968.10 -) male, Han, Associate Professor , Doctoral, Research direction: Design theory and method. 